\title{
PENGENALAN KOPERASI ADAT DI BANJAR TEGALSARI KOTA DENPASAR
}

\author{
I.G.W.M. Yasa ${ }^{1}$, N.P.W. Setyari ${ }^{2}$, I.B.P. Purbadharmaja ${ }^{3}$, S. Arka ${ }^{4}$, I.G. Indrajaya ${ }^{5}$, \\ I.W. Sukadana ${ }^{6}$, K.S. $\mathrm{Nata}^{7}$, dan W. Wenegama ${ }^{8}$
}

\begin{abstract}
ABSTRAK
Koperasi sudah diperkenalkan sebagai strategi pemberdayaan ekonomi lemah yang dilakukan oleh Pemerintah, dunia usaha dan masyarakat, dalam rangka menumbuhkan iklim usaha secara kekeluargaan berdasarkan azas gotongroyong. Berkembangnya koperasi sebagai usaha masyarakat agar mampu memperkuat dirinya sebagai badan usaha yang tangguh dan mandiri. Koperasi dapat tumbuh dan berkembang secara baik jika dijiwai oleh akar budaya nasional yang telah disarikan dalam falsafah negara yakni, Pancasila, dan Undang-Undang Dasar 1945 yang terjalin erat dalam bentuk azas kekeluargaan. Oleh sebab itulah maka, koperasi merupakan soko guru perekonomian Nasional. Kehidupan bermasyarakat di Bali telah lama dikenal dengan eratnya kekerabatan dan kekeluargannya yang ditopang dengan sistem Banjar. Banjar menjadi komunitas adat utama masyarakat Bali dalam kehidupan kesehariannya, sehingga fungsi Banjar menjadi lebih kompleks dibandingkan hanya sebagai identitas. Koperasi adat menjadi salah satu pilihan Banjar, dalam hal ini, Banjar Tegal Sari, Panjer untuk membantu kebutuhan masyarakatnya terutama dalam hal yadnya. Karena itu pendampingan masyarakat ini dirasa perlu untuk dapat membuka jalan terbentuknya koperasi adat yang akan membantu masyarakat secara nyata.
\end{abstract}

Kata Kunci : Koperasi, Banjar, krama adat, Kota Denpasar, Kesejahteraan Masyarakat

\begin{abstract}
Cooperative is a strategy for weak economic empowerment conducted by the Government, business community and society, in the framework of cultivating a business climate on the principle of mutual cooperation. The development of cooperatives as a community effort to be able to strengthen themselves as a tough and independent business entity. Cooperatives can grow and develop properly if imbued by the roots of national culture that has been abstracted in the philosophy of the state, Pancasila, and the 1945 Constitution is established in the form of familial principles. The social life in Bali has long been known as the closeness of kinship and its family supported by the banjar system. Banjar became the main indigenous community of Balinese in their daily lives, so the function of Banjar becomes more complex only as identity. Indigenous cooperatives become one of the Banjar option, in this case, Banjar Tegal Sari, Panjer to help the needs of the community in terms of yadnya. Therefore, this community assistance is deemed necessary to open the way for the formation of adat cooperatives that will help the community in a real way.
\end{abstract}

Keywords : cooperative, banjar, indigineous community, Denpasar city, community wealfare.

\footnotetext{
${ }^{1}$ Corresponding author: N.P.W Setyari, email: wiwin.setyari@gmail.com.

1-8 Staf Pengajar Jurusan Ekonomi Pembangunan, Fakultas Ekonomi dan Bisnis, Universitas Udayana
} 


\section{PENDAAHULUAN}

Koperasi di Indonesia, menurut UU tahun 1992, didefinisikan sebagai badan usaha yang beranggotakan orang-seorang atau badan hukum koperasi dengan melandaskan kegiatannya berdasarkan prinsip-prinsip koperasi sekaligus sebagai gerakan ekonomi rakyat yang berdasar atas asas kekeluargaan. Di Indonesia, prinsip koperasi telah dicantumkan dalam UU No. 12 Tahun 1967 dan UU No. 25 Tahun 1992. Prinsip koperasi di Indonesia kurang lebih sama dengan prinsip yang diakui dunia internasional dengan adanya sedikit perbedaan, yaitu adanya penjelasan mengenai SHU (Sisa Hasil Usaha). Prinsip koperasi adalah suatu sistem ide-ide abstrak yang merupakan petunjuk untuk membangun koperasi yang efektif dan tahan lama (Hans, 1980). Prinsip koperasi terbaru yang dikembangkan International Cooperative Alliance (Federasi koperasi non-pemerintah internasional) adalah: 1) Keanggotaan yang bersifat terbuka dan sukarela; 2) Pengelolaan yang demokratis; 3) Partisipasi anggota dalam ekonomi; 4) Kebebasan dan otonomi; 5) Pengembangan pendidikan, pelatihan, dan informasi.

Di Indonesia sendiri telah ada UU No. 25 tahun 1992 tentang Perkoperasian. Prinsip koperasi menurut UU no. 25 tahun 1992 adalah: 1) Keanggotaan bersifat sukarela dan terbuka; 2) Pengelolaan dilakukan secara demokrasi; 3) Pembagian SHU dilakukan secara adil sesuai dengan jasa usaha masing-masing anggota; 4) Pemberian balas jasa yang terbatas terhadap modal; 5) Kemandirian; 6) Pendidikan perkoperasian; 7) Kerjasama antar koperasi. Prinsip koperasi berdasarkan UU No. 17 Th. 2012, yaitu modal terdiri dari simpanan pokok dan surat modal koperasi (SMK). Apabila koperasi menyelenggarakan satu fungsi maka dapat disebut koperasi tunggal usaha (single purpose cooperative), sedangkan koperasi yang menyelenggarakan lebih dari satu fungsi disebut koperasi serba usaha (multi purpose cooperative). Kemungkinan koperasi untuk memperoleh keunggulan komparatif cukup besar mengingat koperasi mempunyai potensi kelebihan antara lain pada skala ekonomi, aktivitas yang nyata, faktor-faktor precuniary, dan lainlain.

Pertumbuhan Koperasi di Bali demikian pesat dan NPLnya (tunggakan pinjaman) rendah, pengembalian angsuran dari anggota lancar. Kelancaranpengembalian angsuran anggota Koperasi, ditunjang oleh kesadaran para anggota,bahwa Koperasi adalah miliknya. Maju mundurnya Koperasi, ditentukan olehanggota, jika anggota menginginkan Koperasi tumbuh dan berkembang demimeningkatkan kesejahteraan anggota, maka setiap anggota wajib bekerja keras,untuk memajukan Koperasi. Perkembangan Koperasi di Bali, demikian pesat dari segi permodalan maupun dari segi kelembagaan.

Kehidupan bermasyarakat di Bali telah lama dikenal dengan eratnya kekerabatan dan kekeluargannya yang ditopang dengan sistem Banjar. Banjar menjadi komunitas adat utama masyarakat Bali dalam kehidupan kesehariannya,sehingga fungsi Banjar menjadi lebih kompleks dibandingkan hanya sebagai identitas. Pariaman Sinaga (2008) menyebutkan bahwa koperasi sebagai badan usaha masyarakat, dipengaruhi oleh lingkungan internal (sumber daya manusia, modal, pemasaran, dan teknologi), serta lingkungan eksternal (budaya masyarakat, kebijakan pemerintah, perkembangan ekonomi masyarakat, dan pelaksanaan hukum). Oleh karena itu, perkembangan koperasi di Bali, didukung oleh tumbuhnya nilai-nilai budaya yang menjiwai kesadaran masyarakat Bali, untuk ber-keporasi. Pandangan budaya Bali terhadap koperasi, dapat mempengaruhi prilaku masyarakat untuk menumbuhkembangkan kesejahteraan bersama, melalui Koperasi Adat. Tata krama pergaulan masyarakat, diikat oleh adat istiadat, yang disebut organisasi Desa Pakraman, Banjar, dan Sekaa. Pola hidup berorganisasi melalui wadah ini, membiasakan mereka taat pada aturan yang telah disepakati, baik tertulis maupun tidak tertulis, yang disebut awig-awig atau perarem. Pelanggaran terhadap aturan tertulis, maka kena sanksi sesuai tingkat kesalahan, namun jika melanggar aturan tidak tertulis akan menerima akibat sanksi moral. Hukuman perasaan, merupakan akibat dari sanksi moral, untuk menumbuhkan budaya malu. Malu 
I.G.W.M. Yasa, N.P.W. Setyari, I.B.P. Purbadharmaja, S. Arka, I.G. Indrajaya, I.W. Sukadana, K.S. Nata, dan W. Wenegama

berbuat salah, malu punya hutang, malu menyakiti perasaan orang lain dan malu jika mengingkari janji.

Salah satu desa adat yang ada dalam area Kota Denpasar adalah Desa Panjer. Desa Pakraman Panjer terletak di Kecamatan Denpasar Selatan, Denpasar dengan batas-batas wilayah sebagai berikut; di sebelah utara berbatasan dengan Desa Pakraman Yang Batu dan Desa Pakraman Tanjung Bungkak. Di sebelah timur berbatasan dengan Desa Pakraman Renon. Di sebelah selatan berbatasan dengan Desa Pakraman Sidakarya dan di sebelah barat berbatasan dengan Desa Pakraman Sesetan. Desa Pakraman Panjer terdiri dari sembilan banjar pakraman yakni: 1) Br. Kangin, 2). Br. Kaja, 3) Br. Celuk, 4) Br. Antap, 5) Br. Bekul, 6) Br. Sasih, 7) Br. Tegalsari, 8) Br. Maniksaga, dan 9) Br. Kertasari.

Panjer adalah salah satu wilayah di daerah penyanggah pembangunan kota, yang cukup strategis dipandang dari segala sudut - dekat dengan pusat pemerintahan, banyak lembaga pendidikan lanjutan dan berada pada pusat bisnis Denpasar. Namun, keberadaan ini bisa berhasil terbalik bila konsep pembangunannya tidak matang. Karena, akan berimbas negatif pada tatanan kehidupan sosial ekonomi masyarakatnya. Selain itu juga akan tumbuh pemukiman-pemukiman tak beraturan, yang lambat laun menimbulkan kekumuhan dan dapat merangsang tumbuh-kembangnya zona kriminalitas. Hal tersebut menjadi salah satu kebijakan pembangunan di Kelurahan Panjer. Pemerintah kelurahan seringkali melakukan rembug warga berkenaan fenomena pertumbuhan komunitasnya, baik secara kedinasan (kaling) maupun dengan komponen lain.

Salah satu yang muncul dalam rembug ini adalah pentingnya peran banjar dalam membantu masyarakat mengatasi kesulitan mereka terutama dalam hal peson-peson yang wajib diberlakukan sebagai bentuk tanggung jawab warga adat serta sebagai alternative pembiayaan dalam skala kecil. Banjar Tegal Sari, sebagai salah satu banjar adat di wilayah Panjer, memiliki anggot kurang lebih 176 kepala keluarga dengan mata pencaharian mayoritas sebagai pegawai dan usaha kecil berupa warung atau toko. Terbentuknya koperasi adat merupakan salah satu media yang dirasakan akan sangat membantu keseharian warga adat saat ada upacara adat yang membutuhkan peson-peson ataupun pengeluaran rutin.

\section{METODE PELAKSANAAN}

Metode yang dianggap sesuai dengan tujuan pengabdian ini adalah metode ceramah dalam rembug warga yang diselenggarakan di balai banjar terkait. Metode ini dianggap tepat karena dapat mengumpulkan warga secara bersama-sama dalam suasana yang informal sehingga tercapai kesesuaian antara harapan masyarakat dengan keilmuan yang ingin dibagi oleh tim pelaksana. Khalayak sasaran dalam pengabdian ini adalah warga adat Banjar Tegal Sari, Panjer. Hal ini dikarenakan ide pendirian koperasi adat ini memang awalnya ditujukan untuk membantu warga yang merupakan anggota adat setempat.

\section{HASIL YANG DICAPAI}

Banjar Tegal Sari merupakan salah satu banjar adat yang masuk dalan wilayah Kelurahan Panjer, Kecamatan Denpasar Selatan. Secara geografi, lokasi Banjar Tegal Sari masuk wilayah perkotaan dengan jumlah penduduk yang cukup padat. Jumlah penduduk yang masuk dalam keanggotan banjar adat sebanyak $176 \mathrm{KK}$, sedangkan anggota banjar dinas $420 \mathrm{KK}$. Banjar Tegal Sari merupakan banjar bentukan dari warga pendatang saat itu. Pendiri awal Banjar Tegal Sari 
menerapkan aturan-aturan adat yang relatif lebih fleksibel dibandingkan dengan aturan adat desa lainnya. Hal ini didasarkan pada pemikiran jika saat itu, seluruh warga adat Banjar Tegal Sari juga masih memiliki kewajiban adat di tempat asalnya masing-masing.

Seperti halnya karakteristik penduduk perkotaan pada umumnya, pekerjaan warga banjar mayoritas merupakan pegawai, dan memang tidak ada lahan yang dimanfaatkan untuk pertanian, perkebunan, ataupun peternakan. Luas lahan yang cukup sempit menjadikan pemanfaatan ruang menjadi sangat terbatas. Hal yang paling mencolok dari wilayah Banjar Tegal Sari adalah keberadaan warungwarung di sepanjang jalan. Potensi ekonomi yang dimiliki Banjar Tegal Sari sangat strategis dalam mengembangkan ekonomi kerakyatan. Salah satu indikasi pendukung berkembangnya daerah tersebut sebagai kawasan pendidikan yang banyak memberikan peluang masyarakat dalam membuka usaha kecil dari menjual jajan Bali hingga kepentingan pelajar dan mahasiswa. Potensi yang dimiliki oleh lingkungan sepertinya coba dimanfaatkan secara optimal oleh Prajuru Banjar dan masyarakatnya. Banjar adat maupun banjar dinas secara rutin mendapatkan penghasilan dari iuran wajib (misalnya keanggotaan Banjar Adat/Dinas) dan pungutan dari beberapa fasilitas umum yang dikelola (misalnya tempat parkir umum dan sekolah PAUD). Di sisi lain, warga adat maupun warga dinas juga dibebani pungutan, mulai dari yang bersifat wajib maupun "punia" yang juga secara rutin harus dibayar. Sebagai bagian dari komunitas adat, warga memiliki kewajiban secara rutin untuk melaksanakan piodalan baik di tingkat banjar dan desa untuk beberapa Pura yang "disungsung" bersama.

Beberapa pihak berpendapat jika beban sosial dari pelaksananaan adat dan pelestarian budaya menjadi salah satu penyebab yang memengaruhi angka kemiskinan di Bali. Berdasarkan hasil survei dan sensus nasional (Susenas) periode Maret 2014 yang sudah diumumkan Badan Pusat Statistik menunjukkan bahwa persentase penduduk miskin di Bali meningkat menjadi 4,53 persen dari periode sebelumnya pada September 2013 sebesar 4,49 persen. Hal yang menarik perhatian adalah item pengeluaran masyarakat miskin. Dari survei yang dilakukan terhadap komponen pengeluaran non makanan, keperluan untuk upacara agama menempati posisi kedua setelah perumahan. Sementara pengeluaran untuk kesehatan dan pendidikan mendapat porsi lebih kecil (https://www.beritabali.com). Fenomena ini yang kemudian memunculkan anggapan jika ritual keagamaan dan adat telah menjadi jerat kemiskinan di Bali. Beban sosial adat yang ditanggung masyarakat cukup berpengaruh terhadap pengeluaran penduduk miskin. Meskipun pemerintah sudah memberikan beberapa jenis bantuan penanggulangan kemiskinan, seperti beras miskin.

Kesibukan sosial di Bali memang memiliki intensitas yang cukup tinggi. Intensitas kegiatan adat yang cukup tinggi tentu saja akan berimbas ada bertambahnya biaya yang harus dikeluarkan untuk pelaksanaannya. Jika dipandang dari opportunity cost, maka waktu yang tersita untuk mengikuti kegiatan tersebut berkorelasi dengan hilangnya pendapatan yang mungkin diterima oleh seorang individu jika waktu itu digunakan untuk bekerja. Selama ini beban sosial terhadap adat dan budaya yang harus ditanggung antara yang miskin dan kaya itu sama, sehingga masyarakat miskin kita menjadi tinggi sekali beban yang harus ditanggung. Selain memang ada pula desa pakraman atau desa adat yang memberlakukan kebijakan yang ujung-ujungnya berimbas memberatkan masyarakat. Apabila beban-beban social terhadap adat dan budaya tersebut tidak mungkin untuk dihilangkan, maka beban tersebut masih mungkin untuk dapat "dibagi" beratnya, sehingga tidak menimbulkan ketimpangan yang semakin besar. Melalui sebuah ide untuk membuat koperasi, merupakan cara masyarakat untuk meminta bantuan atas solusi tersebut.

Merujuk pada UU No. 17 Tahun 2012 tentang Perkoperasian, Koperasi adalah badan hukum yang didirikan oleh orang perseorangan atau badan hukum Koperasi, dengan pemisahan kekayaan para anggotanya sebagai modal untuk menjalankan usaha, yang memenuhi aspirasi dan kebutuhan bersama di bidang ekonomi, sosial, dan budaya sesuai dengan nilai dan prinsip Koperasi. Definisi yang diberikan memberikan makna yang cukup berbeda dengan makna Koperasi pada UU

\section{9 | BULETIN UDAYANA MENGABDI}


I.G.W.M. Yasa, N.P.W. Setyari, I.B.P. Purbadharmaja, S. Arka, I.G. Indrajaya, I.W. Sukadana, K.S. Nata, dan W. Wenegama

sebelumnya, UU No. 25 Tahun 1992 dimana Koperasi adalah badan usaha yang beranggotakan orang-seorang atau badan hukum Koperasi dengan melandaskan kegiatannya berdasarkan prinsip Koperasi sekaligus sebagai gerakan ekonomi rakyat yang berdasar atas asas kekeluargaan. Jika pada UU yang lama, koperasi difokuskan untuk menggerakkan ekonomi rakyat, maka di UU Koperasi yang baru pemenuhan kebutuhan ekonomi, sosial, dan budaya menjadi tujuan pembetukannya. Hal ini berarti, sepanjang memenuhi nilai dan prinsip koperasi. Nilai yang mendasari kegiatan Koperasi yaitu: a. kekeluargaan; b. menolong diri sendiri; c. bertanggung jawab; d. demokrasi; e. persamaan; f. berkeadilan; dan g. kemandirian. Sedangkan yang dimaksud dengan prinsip Koperasi meliputi: a. keanggotaan Koperasi bersifat sukarela dan terbuka; b. pengawasan oleh Anggota diselenggarakan secara demokratis; c. Anggota berpartisipasi aktif dalam kegiatan ekonomi Koperasi; d. Koperasi merupakan badan usaha swadaya yang otonom, dan independen; e. Koperasi menyelenggarakan pendidikan dan pelatihan bagi Anggota, Pengawas, Pengurus, dan karyawannya, serta memberikan informasi kepada masyarakat tentang jati diri, kegiatan, dan kemanfaatan Koperasi; f. Koperasi melayani anggotanya secara prima dan memperkuat Gerakan Koperasi, dengan bekerja sama melalui jaringan kegiatan pada tingkat lokal, nasional, regional, dan internasional; dan g. Koperasi bekerja untuk pembangunan berkelanjutan bagi lingkungan dan masyarakatnya melalui kebijakan yang disepakati oleh Anggota.

Secara konsep, Koperasi menjadi bentuk usaha ekonomi yang sangat tepat untuk menjawab kegelisahan warga atas beban sosial keadatan dan budaya yang harus mereka tanggung setiap waktunya. Karena itu, tema dalam kegiatan pengabdian yang dibawa oleh Tim sangat disambut baik. Pengabdian dilakukan dengan metode ceramah yang lebih banyak diisi dengan pengalamanpengalaman empiris yang dibagikan kepada masyarakat adat di Banjar Tegal Sari. Hampir seluruh anggota masyarakat menyatakan tidak pernah mendengar konsep tentang koperasi adat sebelumnya. Koperasi yang mereka tahu, adalah koperasi dalam artian umum, yaitu sekumpulan orang yang atas dasar kesepakatan bersama membentuk satu gerakan dalam upaya meningkatkan kesejahteraan anggotanya dalam konteks sosial dan ekonomi. Munculnya istilah "koperasi adat" cukup menarik perhatian mereka. Istilah "koperasi adat" menjadi menarik karena di Bali sendiri, unit usaha ekonomi yang berbasis adat yang paling terkenal adalah Lembaga Perkreditan Desa (LPD). Hanya saja, secara aturan LPD hanya boleh didirikan di wilayah Desa Adat (bukan banjar pekraman) dan didasarkan pada Perda yang revisi terakhir pada Perda No. 3 tahun 2017. Karena dasar hukumnya adalah Perda, maka LPD menjadi satu-satunya lembaga keuangan yang tidak berada di bawah pengawasan Otoritas Jasa Keuangan (OJK). Seperti diketahui bersama, ruang lingkup LPD hanya dibatasi pada wilayah desa adat dimana dia berdiri, dan pertanggungjawabannya hanya sampai pada krama adat di desa tersebut.

Karena itu, konsep koperasi adat akan berbeda secara teknis dengan LPD, sekalipun operasionalnya serupa dengan LPD. Karena merujuk pada bentuk koperasi, maka koperasi adat secara hukum akan berada di bawah UU Koperasi. Karena itu, seperti koperasi pada umumnya, pengawasan akan berada di bawah pemerintah, dalam hal ini Dinas Koperasi Kota Denpasar. Mengacu pada bentuk hukum koperasi, maka ada beberapa kewajiban yang harus diikuti dalam proses pembentukannya. Seperti yang diamanatkan dalam UU, untuk pembentukan sebuah koperasi primer minimal ada 20 orang yang bersepakat menjadi anggota koperasi dengan memisahkan hartanya menjadi modal awal koperasi. Akta pendirian, yang didalamnya memuat Anggaran Dasar dan keterangan lainnya yang berkaitan dengan pendirian koperasi haruslah disahkan oleh Notaris.

Koperasi adat, merujuk pada berbagai hal yang diatur dalam Anggaran Dasar koperasi berdasarkan pada aturan adat. Wilayah keanggotaan misalnya, hanya membatasi pada masyarakat yang memang merupakan anggota banjar adat (krama adat) di wilayah koperasi tersebut berdiri. Tata cara pengangkatan, penggantian, dan pemberhentian pengawas dan pengurus dapat mengikuti system 
LPD, yang menyerahkannya pada mekanisme "parum banjar". Hal ini dimaksudkan untuk tetap menjaga eksistensi adat dalam membentengi perubahan yang mungkin dapat merugikan koperasi. Ketentuan mengenai sanksi juga dipandang tepat jika koperasi adat dapat mengikuti pola LPD. Karena syarat keanggotaan yang diatur hanya mengijinkan krama adat sebagai anggota, maka sanksi adat juga dapat diberlakukan untuk mengikat anggota dalam kewajiban yang sama. Seperti diketahui, adat Bali tidak membedakan masyarakatnya dalam kelompok mampu dan tidak mampu, sehingga semua diperlakukan sama. Penerapan sanksi adat dirasakan lebih berat oleh masyarakat dibandingkan dengan sanksi hokum lainnya. Sehingga, dapat dipastikan jika masyarakat akan lebih taat pada sanksi adat. Karena itu, jika koperasi menggunakan dasar adat dalam pelaksanannya, maka jalannya koperasi tersebut diharapkan jauh lebih sehat dan sesuai dengan peruntukannya.

Masalah sumber daya manusia menjadi potensi masalah yang mungkin muncul dalam proses pendiriannya. Hal ini disebabkan karena Banjar Tegal Sari merupakan banjar yang diisi oleh pendatang dan mayoritas merupakan pekerja kantoran. Karena itu, guna mendukung penguatan pendirian koperasi adat, terutama di awal, maka dibutuhkan komitmen dan kesediaan yang ikhlas dari anggota banjar yang memang bersedia untuk "ngayah". Ngayah adalah kewajiban sosial masyarakat Bali sebagai penerapan ajaran karma marga yang dilaksanakan secara gotong royong dengan hati yang tulus ikhlas baik di banjar maupun di tempat suci. Kata ngayah secara harafiah dapat diartikan melakukan pekerjaan tanpa mendapat upah. Tokoh yang bersedia "ngayah" ini dapat dipastikan harus jujur, tangguh, dan visioner, sehingga dapat menggerakkan koperasi tersebut. Apabila koperasi tersebut sudah berjalan dengan baik, maka menggerakkan anggota masyarakat yang lainnya akan menjadi lebih mudah. Komitmen, gotong royong, dan toleransi menjadi kunci berjalannya koperasi ini dengan baik..

\section{KESIMPULAN}

Koperasi adalah gerakan ekonomi yang berbasis pada upaya bersama untuk meningkatkan kesejahteraan sosial dan ekonomi anggotanya. Merujuk pada system kerja koperasi dan mengkombinasikannya dengan aturan adat, maka koperasi adat ini memiliki peluang yang tinggi untuk bisa berhasil. Hal ini karena sistem aturan masyarakat adat yang menjadi dasar akan memberikan ikatan emosional yang lebih baik. Hal ini menjadikan daya dorongnya lebih mudah dan cepat. Karena itu semua dasarnya adalah kepercayaan, seperti halnya lembaga keuangan lainnya.

Ide pendirian koperasi adat menjadi sangat menarik untuk dapat betul-betul diaplikasikan. Hal ini menarik, karena jika koperasi yang didirikan di wilayah banjar pekraman, maka pelindungnya menjadi lebih jelas, yaitu Prajuru Banjar. Fungsi utama yang menjadi penciri dari sebuah koperasi adat adalah tujuan pendiriannya untuk meringankan suka duka krama, dan bukan bertujuan konsumtif. Payung hukum untuk aturan sanksi dapat menggunakan sanksi-sanksi adat yang telah disepakati bersama. Kesadaran pribadi, akan membuat masyarakat untuk menjaga keberlangsungan koperasi.Melihat proses dan hasil yang diperoleh saat pengabdian awal di Banjar Tegal Sari, pengabdian serupa dapat dilaksanakan di wilayah lain.

\section{DAFTAR PUSTAKA}

O'Sullivan, Arthur; Steven M. Sheffrin. 2003. Economics: Principles in action. Upper Saddle River, New Jersey 07458: Pearson Prentice Hall

Hans. 1980. Prinsip-prinsip Koperasi dan Undang-undang Koperasi, Direktorat Jenderal Koperasi

Hendar dan Kusnadi. 2005. Ekonomi Koperasi. Lembaga Penerbit FEUI

Sinaga, Pariaman dkk. 2008. Koperasi Dalam Sorotan Peneliti. Jakarta : PT. Grafindo Persada.

UU No. 17 Tahun 2012 Tentang Perkoperasian.

\section{1 | BULETIN UDAYANA MENGABDI}

